\title{
Zinc therapy for acute diarrhea in children under three years of age
}

\author{
Nicoleta Negruț \\ From The 10th Edition of the Scientific Days of the National Institute for Infectious Diseases "Prof Dr Matei \\ Bals" \\ Bucharest, Romania. 15-17 October 2014
}

\section{Background}

Zinc therapy is recommended by WHO and UNICEF in acute diarrhea in children under 5 years old.

\section{Methods}

The study's outcome was to investigate the efficacy of the zinc treatment in children aged 0-3 years, from the region of Bihor, Romania, with acute diarrhea. Zinc sulfate (10-20 $\mathrm{mg}$ daily, according to age) was given to the patients in the study group for 10 days. All children were followed up over a period of 3 months for new episodes of diarrhea. Data were processed using IBM SPSS statistics version 22.

\section{Results}

During 2009-2011, 116 children with acute diarrhea from Bihor country, Romania, were enrolled in the study. From initial group, 103 children were available for final analysis. The duration of diarrhea in the study group $(n=53)$ as compared to control $(\mathrm{n}=50)$ was reduced by 24 hours (1.94 \pm 0.7 days versus $2.4 \pm 1.2$ days, $p<0.001$, Student's $t$ test). Diarrheic episodes in the next three months occurred more frequently in the control group (3.8\% versus $16 \%, \mathrm{p}=0.036$, Student's t test).

\section{Conclusion}

Zinc supplementation has a significant effect on the duration of acute diarrhea. The mineral can reduce the frequency of acute diarrhea in the next 3 months.

\section{Acknowledgement \\ Financing of this study was supported by own sources}

Published: 15 October 2014

Correspondence: Inm_n10@yahoo.com

Faculty of Medicine and Pharmacy, University of Oradea, Romania

Submit your next manuscript to BioMed Central and take full advantage of:

- Convenient online submission

- Thorough peer review

- No space constraints or color figure charges

- Immediate publication on acceptance

- Inclusion in PubMed, CAS, Scopus and Google Scholar

- Research which is freely available for redistribution

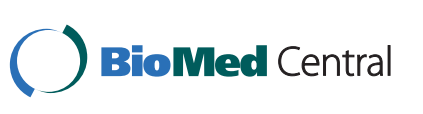

(C) 2014 Negrut; licensee BioMed Central Ltd. This is an Open Access article distributed under the terms of the Creative Commons Attribution License (http://creativecommons.org/licenses/by/4.0), which permits unrestricted use, distribution, and reproduction in any medium, provided the original work is properly cited. The Creative Commons Public Domain Dedication waiver (http:// creativecommons.org/publicdomain/zero/1.0/) applies to the data made available in this article, unless otherwise stated. 